\title{
新潟県のクロキンバエ，特に近年における その多発について
}

On the green bottle fly, Phormia regina in Niigata Prefecture, with particular reference to the large occurrence in recent years

斉藤 奨斎藤豊

Susumu Saito and Yutaka Saito

クロキンバエ Phormia regina はポリオ・ビールスを 生物学的に伝播する可能性があるという主として実験的 根拠（Melnick, 1947，1949）に基いて，少なくとも米 国においては注目されている種類である.日本における 本種の分布はほとんど北海道だけに限られていたよらで 本州からの採集報告は極めて少ない，たまたま著者らは 1964 年 6 月 16 日の新潟地震老契機として八エの採集を 行い，新潟県下にクロキンバェが多発していることを知 つた。すなわち新潟地震で大被害を受けた新潟市信濃川 沿岸地带に対して, 新潟県および市当局は衛生害虫駆除 対策の 1 つしてへリコプターによる殺虫剤の空中散布 を実施した，著者らはその機会に力，八エに対する薬剤 効果ならびにそれらの発生状況を観察してみた.八エは 魚内臟を誘引物としたハエトリカゴを用い，7月4日か ら13日まで連日採集につとめたところ，クロキンバェが 採集した八エ総数の $0.3 \sim 9.7 \%$ に含まれているといら 興味ある事実に遭遇した. そこで著者らはひきつづき新 潟市における本種の発生状況を調べ，更に新潟県下の諸 地域においても調查を行つた. その結果, クロキンバェ が県下全般にわたり，かなり多く採集されたので, 著者 らの過去の成績と比較しながら, 本種の発生分布の推移 を記述し，各位の参考に供したい。

1. 本州北部におけるクロキンバエの過去の採集記録

堀克重 (1951) は岩手県盛岡市からクロキンバエの雄 1 個体を採集し，本州における最初の記録となつた。その 後, 斎藤豊ら (1955)は新潟県で, 加納六郎ら (1964)は青 森, 秋田, 岩手, 山形県で, 倉橋弘(1965) 注石川県でそれ ぞれ採集し，本州におけるクロキンバエの分布状況が次 第にあきらかとなつた．新潟県においては，1954年に斉

新潟大学医学部医動物学教室 (主任: 大鶴正満教授) Department of Medical Zoology, Niigata University School of Medicine (Head: Prof. Masamitsu Otsuru)
藤豊（1955）が新潟市の八エ 9,988 個体を調べたが，ク ロキンバエは証明されなかつた。翌 1955 年に都藤豊ら (1956) は新潟県の各地で夏期を中心に戸外の八エ30,751 個体を採集し，直江津の八エ 952 個体の中から県下で初 めてクロキンバェ雄 5 個体をみつけ，それはクロバエ科 702 個体の約 $0.7 \%$ に相当した. ついで斉藤奨 (未発表) は 1958～59 年の 2 年間, 新潟市の八工を調心，ク口キ ンバエは 58 年に採集した八エ 16,749 個体には含まれて いなかつたが, 翌 59年の八エ 18,132 個体からその雌 2 個 体 (8月上旬)が見出された. その後 4 年を経た 1963 年 4 ～12月の間, 著者らの 1 人, 斉藤豊は各月の中句に新潟市 新大医学部構内の八エ採集を行つた（その1部は東京医 科歯科大学医学部医動物学教室加納六郎教授のもとで同 定された).これらの中には 10月を除く5〜11月の閒合計 60 個体のクロキンバエがみられ, それは検查総数 8,954 の $0.7 \%$ ，クロバ土科 5,876 の $1.0 \%$ を占めていた.

2. 1964 年の新潟県におけるクロキンバエの調査

a) 新潟市 新潟地震以後の 1964 年 7月 4 17日の 間，市内の 7 個所で八エ採集を行つた. 採集した八エは 合計 20,323 個体で，クロバェ科が圧倒的に多く 17,827 $(87.7 \%)$, 以下ニクバエ科 $1,407(6.9 \%)$, イエバエ科 $951(4.7 \%)$, 八ナバェ科 $138(0.7 \%)$ の順であつた. クロ キンバエは採集した全個所から合計 742 個体がえられ， 総数の $3.6 \%$ ，クロバェ科の $4.2 \%$ 占めた. すなわち 薬剤効果判定の目的から八エトリカゴを設固した新潟市 (7月 4〜13日) の河渡はクロキンバェ 56 個体をえて総 数 1,469の $3.8 \%$, クロバェ科 1,278 の $4.4 \%$, 以下同 様に小金町は 140 をえて 4,779の $2.9 \%, 3,863$ の 3.6 $\%$ ，藤見町は 579 をえて 11,002 の $0.5 \%, 8,141$ の 0.7 $\%$, 新大医学部構内 (迏町) は 71 をえて 3,447 の $2.1 \%$, 2,692 の $2.6 \%$ ，その後できるだけ市内全般を観察する 目的で新たに選定した新潟市（7月 15〜17日）の流作場 はクロキンバェ 36 個体をえて 総数 922 の $3.9 \%$ ，クロ 
表 1 新潟県におけるクロキンバエの採集成績（1964 年）

\begin{tabular}{|c|c|c|c|c|c|c|c|c|c|}
\hline 地 & 区 & 月 & 採集回数 & $\begin{array}{l}\text { Phormia } \\
\text { regina }\end{array}$ & Calliphoridae & $\begin{array}{l}\text { Sarco- } \\
\text { phagidae }\end{array}$ & Muscidae & $\begin{array}{l}\text { Antho- } \\
\text { myiidae }\end{array}$ & 計 \\
\hline 新 発 & 田 & $8.7 \sim 22$ & 3 & $4(1.0)$ & $284(73.8)$ & $79(20.5)$ & $21(5.5)$ & $1(0.2)$ & 385 \\
\hline 新 & 潟 & $7.4 \sim 9.24$ & 19 & $4,407 \quad(9.7)$ & $37,517(82.8)$ & $3,562(7.8)$ & $3,244 \quad(7.1)$ & $1,144 \quad(2.3)$ & 45,467 \\
\hline 巻 & & $8.8 \sim 9$ & 1 & $2(0.4)$ & $343(65.6)$ & $167(31.9)$ & $13(2.5)$ & 0 & 523 \\
\hline 杤 & 尾 & $8.4 \sim 6$ & 3 & $4(0.5)$ & $573(73.7)$ & $186(23.9)$ & $19(2.4)$ & 0 & 778 \\
\hline 長 & 盛 & $7.17 \sim 22$ & 2 & $18(18.0)$ & $85(85.0)$ & $5(5.0)$ & $8(8.0)$ & $2(2.0)$ & 100 \\
\hline 十日 & 町 & 8.3 & 1 & $2(1.8)$ & $112(100.0)$ & 0 & 0 & 0 & 112 \\
\hline 直 江 & 津 & 7.28 & 1 & $10(0.8)$ & $1,097(92.1)$ & $51 \quad(4.3)$ & $41 \quad(3.4)$ & $2(0.2)$ & 1,191 \\
\hline 両 & 津 & $8.14 \sim 16$ & 2 & $3(0.3)$ & $974(98.4)$ & $11(1.2)$ & $4(0.4)$ & 0 & 989 \\
\hline 相 & 川 & 7.29 & 1 & 0 & $23 \quad(95.8)$ & 0 & $1(4.2)$ & 0 & 24 \\
\hline
\end{tabular}

註 1）（）内は採集総数に対する％，2）採集回数は1地区1日採集を1回とする。

バエ科 681 の $5.3 \%$, 以下同様に関屋本村は 31 をえて 441 の $7.0 \%, 391$ の $7.9 \%$ ，小針は 32 をえて 330 の $9.7 \%, 250$ の $12.8 \%$ あ゙あつた.

b）県内全般 新潟市においてクロキンバエがほとん ど全地域に分布していると考えられたので，ひきつゔき 市内で本種の観察をつふけけとともに, 1964 年 7 月中句 から9月下旬の間, 県内の発生状況についても調查し た. 八エは各保健所に依頼し，八エトリカゴ(魚内臟)で 戸外の八エを採集してもらつた．協力をいただいた保健 所は新発田, 杤尾, 長岡, 十日町, 直江津, 両津および 相川の 7 地区で，著者らの採集した新潟および巻を加え て県内の調查は 9 地区で行われた. その結果, 佳渡島の 相川を除く 8 地区にクロキンバェが採集された(表 1 ). すなわち全地区の八エ 採集総数は 49,568 個体で，その らちクロバエ科が大部分を占め 41,008 個体 $(82.7 \%)$, クロキンバェは 4,450 個体をえて総数の $9.0 \%$, クロバ エ科の $10.8 \%$ であつた. 本種の占める割合が最も高率 であつた長岡は 18 個体をえて総数 100 の $18.0 \%$ ，クロ バェ科 85 の $21.2 \%$ ，最も低率であつた佐渡島の両津は 3 個体をえて総数 989 の $0.3 \%$ ，クロバエ科 974 の 0.3 \%であつた. また最も長期間（7月 4 日〜9月 24 日）観 察された新潟市は 4,407 個体のクロキンバエをえて総数 45,467 の $9.7 \%$ ，クロバエ科 37,517 の $11.7 \%$ であつ た.なお，これらとは別に 1964 年 8 月 16 日，栗島にお いてたまたま採集された 3 個体のキンバエの中にもクロ キンバェ(ㅇ 1)が含まれていた.

c）クロキンバェの生態観察 新潟市で調查した 7 個 所の 万ち新大医学部構内は 1964 年 7 月 4 日から 9 月 24 日の間に計 19 日（回）八工採集が実施された。このう ち 7 月 4 13日の毎日および 7 月 26 日は朝 9 時に八エ トリカゴを設置して翌朝 9 時に回収, 他の 7 月 21 日, 8 月 $2,3,6,18,20$ 日，9月7，24日の 8 日は八エが活 動している日中， 1 時間毎にハエトリカゴを更新して，

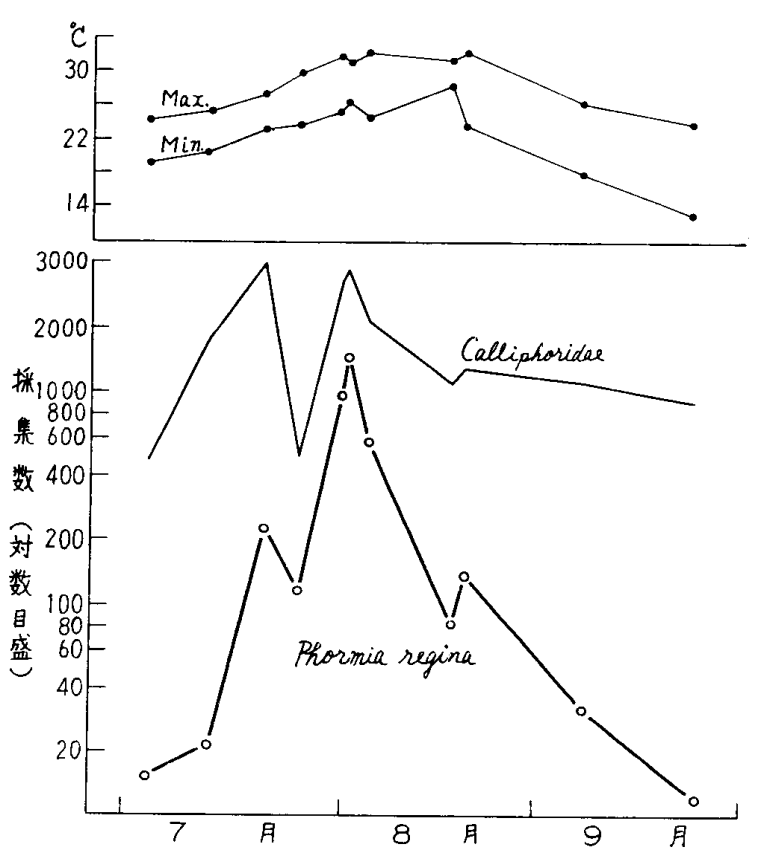

図 1 新潟市におけるクロキンバェの月别消長 月別消長および日週活動を観察した。

月別消長 (図 1)：クロキンバエは調查を始めた 7 月 4 日から活動しており（15 個体採集），日平均気温の上昇 とともに次第に多くなつた. ついで 8 月に入るや急に増 加して上旬（8月 $2 ， 3 ， 6$ 日）に山を示し，しかも当日採 集総数の 20.9 38.7\%它め, ヒロズキンバェPha nicia sericataに次いで 2 位となつた. しかしその後娍少 し, 9 月下旬には少数 (12 個体) しか採集されなかつた。 なお，1964年新大医学部構内における別の観察によ机ば クロキンバェは 4 月下句と 11 月中旬にも採集された。

日週活動：上記のように1時間毎に八エを採集したほ か, そのつど気温, 湿度および照度を測定した. 7〜9月 におけるクロキンバェの日週活動をここでは1日の気温 変化の範囲が $26 \sim 32^{\circ} \mathrm{C}$ と $13 \sim 26^{\circ} \mathrm{C}$ との 2 群に大別し て検討してみた。 その結果, 気温の高い日 $\left(26 \sim 32^{\circ} \mathrm{C}\right)$ においては(図 2)，一般に八工は早朝照度 100〜300 lux 
(186) 衛 生 動 物
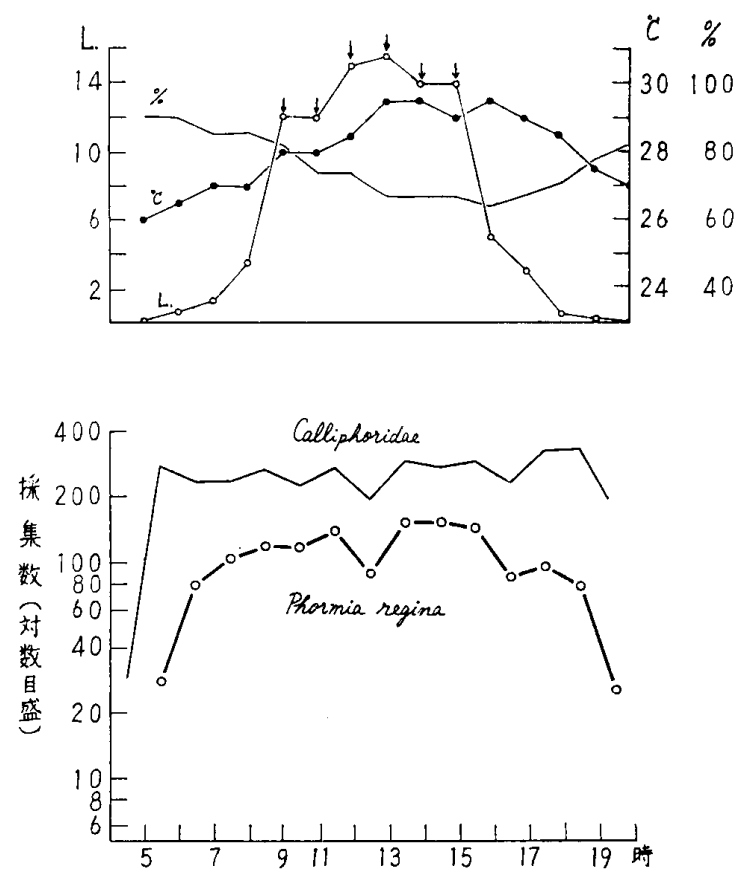

四 2 新舄市におけるクロキンバエの日周活動（Ｉ） 1 日の気温が $26 \sim 30^{\circ} \mathrm{C}$ の場合 (1964.8.3)

註 L. 注度万単位, \% は湿度, $\downarrow$ は直射日光
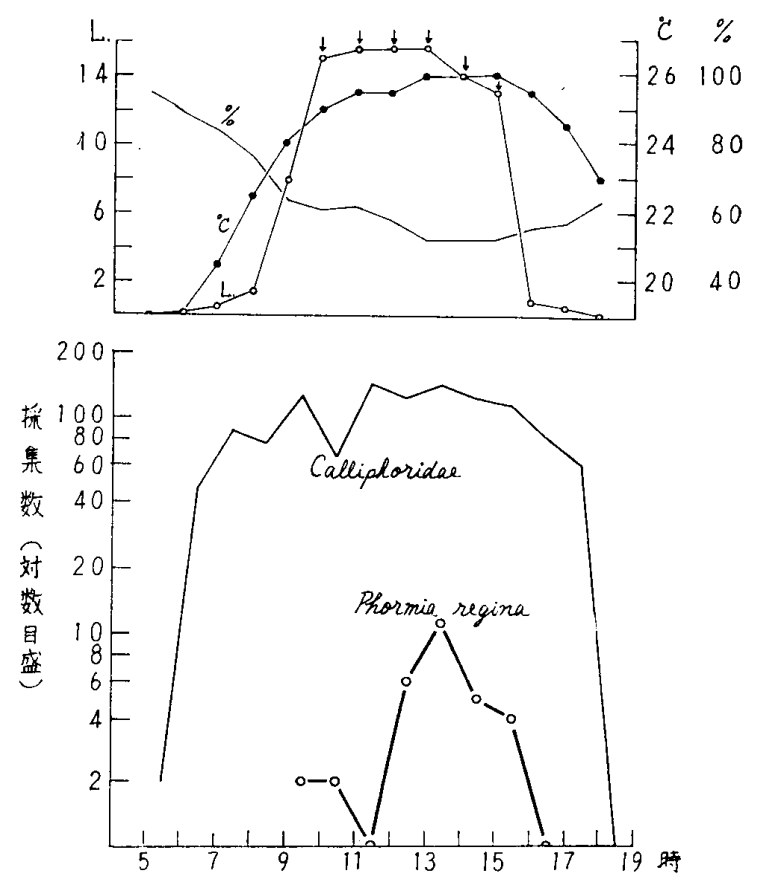

図3新潟市に揖けるクロキンバエの日周活動(II) 1 日の気温が $19 \sim 26^{\circ} \mathrm{C}$ の場合 (1964.9.7)

註 L. は照度万単位，\%は湿度，」は直射日光

から活動を開始したが，クロキンバエは 2,000 lux 以下 で注ほとんど活動しなかつた，その後，時間の経過にと もなつて本種の活動が次第に活発となり, 気温 $\left(\right.$ 約 $\left.32^{\circ} \mathrm{C}\right)$, 照度（約 150,000 lux）が最も高くなる13〜15 時に最高 の山を示し，姿を消したのは薄暮の照度 100 500 lux であった，次に気温が比較的低、日 $\left(13 \sim 26^{\circ} \mathrm{C}\right)$ につい
てみると（図 3 )，照度 500 1,000 lux から一般の八 エの活動がみられたが，クロキンバエは照度 50,000 100,000 lux で初めて活動を開始し，13〜15 時に最高の 山を示して照度 4,000 5,000 lux で早くも姿を消して しまつた。

なお，成虫および幼虫の食性については後日あらため て記述したい。

\section{考察}

クロキンバエはルリキンバエ Protophormia terraenovae とともに北海道では普通種として知られている. 本州における本種の採集報告は, 以前は岩手県の雄 1 個 体(堀，1951) と新潟県の雄 5 個体（斎藤豊ら，1955)だけ であつたが，近年になつてようやく青森，秋田，山形(加! 納ら, 1964) および石川県 (倉橋, 1964) が追加された. 新 潟県の八エについては 1954 年および 1955 年に斎藤豊ら が，1958 年および 1959 年には斉藤奖が観察した。 この らちでクロキンバェが採集されたのは 55 年に直江津市 の雄 5 個体, 59 年に新潟市の雌 2 個体で, いずれも北海 道から移入されたものと推定された.ところが1963年, 新 潟市内でクロキンバェ 60 個体を採集し，更に翌 1964 年 には新潟地震 ( 6 月16日)を契機として新潟市をはじめ新 潟県下に広く本種が多発していることを確認し，本州に おける本種の土着の可能性が充分考えられるに至つた。

1964 年の新潟県におけるクロキンバエの分布調查は 9 地区 (新発田, 新潟, 巻, 杤尾, 長岡, 十日町, 直江津, 雨津, 相川) で, そのうち佐渡島の相川を除く 8 地区から クロキンバエが採集され，新潟県下に広く分布している ように思われた. しかも本種は八エ 全採集総数 49,568 . の $9.0 \%$ ，クロバエ科 41,008 の $10.8 \%$ を占め，少なく とも夏期においては新潟県八エ相の主要種であつた。こ れを前年(1963)の本種(総数の $0.7 \%$,クロバエ科の 1.0 $\%$ と)比較してみると, 率で約 10 倍に増加した.

このようなことから，クロキンバェが新潟県下に生息 するようになつたのは数年前と考えられる. その過程は まず北海道から船や汽車で魚などの荷物とともに運ばれ やがて生息 (土着)可能となり, 次第に繁殖増加し, たま たま新潟地震のため環境がみだされたことや，この期間， の害虫駆除対策が効果的に実施されなかつたことなども 手伝つて, 1964 年 7 月上旬頃から多発の傾向を示したも のと想像される.

なお，本種は一般に盛夏に，しかも気温，照度が最高 となる日盛りに最も多数活動したことから，むしろ高温 を好む種類のように思われた．更に別の観察でクロキン バエが 4 月下旬と 11 月中旬にも採集されたことから， 本種の活動は一般に夏期に山を示すが, 早春, 晚秋にお いても出現すると推定された。 


\section{まとめ}

近年，本州におけるクロキンバエの分布は次第にあき らかとなつてきた. 著者らは 1963 年新潟市で 60 個体を, 更に翌 1964 年同市で多数のクロキンバエを採集したこ とから，本種は新潟県にも土着するようになつたと推定 した. そこで 7 月中旬〜 9 月下旬の間, 新潟県における本 種の分布打よびその活動状況を観察し，次の結果をえた。

1） 1963 年 4 12 月の閒，新潟市で八エ採集を行い， 10 月を除く 5 11 月に合計 60 個体のクロキンバエがえ られ，それは総数 8,954 の $0.7 \%$ ，クロバ工科 5,876 の $1.0 \%$ あった.

2) 1964 年 7 9 月の間，新潟県下で採集したクロキ ンバエは合計 4,450 個体で，それは総数 49,568 の 9.0 $\%$ ，クロバエ科 41,008 の $10.8 \%$ を占めており，新潟県 におけるハエの 1 主要種であった.

3） 今回の成績掞よび過去の記録から，本種が新潟県 下に土着するようになつたのは数年前で，その後次第に 増加していることを実証した。

4）本種の活動は 4 月下旬 11月中旬の間で, 気湿の 高い8月に山がみられた。 また 1 日のうちでは天気の良 、盛夏 (気温 $26 \sim 32^{\circ} \mathrm{C}$ ) 注早朝 (照度 $1,000 \sim 2,000 \mathrm{lux}$ ) から薄暮(照度 200 500 lux) まで活動し，特に日盛りに その山がみられ, 初秋(気温 $13 \sim 26^{\circ} \mathrm{C}$ ) は日盛りのみに 活動が限られた。

終りにご校閲をいただいた主任大鶴正満教授，八エの 同定にご協力くだされ，また私信を拉よせいただいた加 納六郎教授ならびに私信をいただいた堀克重博士に深謝 する。な抢本調查に協力された新潟県衛生部, 各保健所 の方々汇謝意を表する。

\section{文献}

1）堀克重 (1951)：東北地方の蠩類. 昆虫, 19(1):2425. - 2) 加納六郎 - 篠永哲 (1964)：東北地方の八工 類. 東北昆虫研究, 1(1)：5-8. - 3) 倉橋弘 (1965)： Phormia regina (Meigen) の新産地. 昆虫, 33(1) : 38. - 4) Melnick, J. L. \& Penner, L. R. (1957): Experimental infection of flies with human poliomyelitis virus. Proc. Soc. Exp. Biol. and Med., 65 : 342-346. - 5) Melnick, J. L. (1949): Isolation of poliomyelitis virus from single species of flies collected during an urban epidemic. Amer. J. Hyg., 49 : 8-16. 一 - 6) 斉藤豊 (1955)：新潟市内に打ける八エの 季節的消長. 衛生動物, $6(1)$ ：35. 一7) 斎藤豊・大鶴 正満・須川豊(1956)：新潟奖の八エについて。衛生動 物, $7(3 \cdot 4): 173-178$.

\section{Summary}

Although the green bottle fly, Phormia regina belonging family Calliphoridae is well known as a common species in Hokkaido, Japan; the occurrence of the fly in Honshu of Japan is almost unknown but with some exceptions: Only the one male collection from Morioka in Iwate Prefecture by K. Hori (1950), the five male collection from Naoetsu in Nigata Prefecture by Y. Saito (1955), collections of this fly from Tohoku District excluding Miyagi and Fukushima Prefectures by R. Kano and S. Shinonaga (1963), and the seventeen males and one female from Kanazawa City by H. Kurahashi (1964).

Some weeks after the great earthquake in northwestern Japan which happened on 16 June 1964, and being called 'Niigata-Earthquake', the insecticide-spraying by helicopters against both mosquitoes and flies of medical importance was carried out early in the next month July. In the course of this practice, accidentally it was noticed that the occurrence of a relatively large number of $P h$. regina was demonstrated in the fly-collections from Niigata City. In view of the fact, further investigations of fly fauna and particularly of $P h$. regina were undertaken in several localities in Niigata Prefecture and compared with the earlier data which had already been obtained by the present authors from the same prefecture during the past several years. The results obtained are as follows:

The total number of flies collected from 9 localities (Niigata, Shibata, Maki, Tochio, Nagaoka, Tokamachi, Naoetsu, Ryotsu and Aikawa) during from July to September 1964, were 49,568 consisting of various genera and species of family Muscidae, Anthomyiidae, Calliphoridae and Sarcophagidae. Of totaled $49,568,4,450(9.0 \%)$, and of totaled 41,008 specimens of Calliphoridae, 4,450 (10.8\%) were the members of $P h$. regina respectively. The flies collected from Niigata City only during the same months were 45,463 in total number, in which $9.7 \%$ of the whole flies and $11.7 \%$ of the flies of Calliphoridae were occupied by the members of $P h$. regina respectively. In $P h$. regina, male by female ratio was almost equall (47.1:52.9) based on the 2,862 specimens trapped in Niigata City during the summer months. As to diurnal and seasonal activities of $P h$. regina, it was found that this fly was most active at lighter and hotter daytime in summer though actually active from late April through summer to mid-November. In the other hand, the flies collected from Niigata City from April to December 1963, were 8,954 in total, of which $5,876(65.6 \%)$ were the flies of Calliphoridae and $0.7 \%$ of the same family were Ph. regina. In 1955, the flies collected from 19 localities in Niigata Prefecture during from April to December were 30,751 in total number and only 5 male specimens of $P h$. regina were found in them. On the basis of those yearly observations, it was newly known that recently $P h$. regina showed a tendency to increase in population year by year in Niigata Prefecture, Honshu, Japan. 